\title{
KORELASI MODEL GROUP INVESTIGATION DENGAN KEMAMPUAN BERPIKIR KREATIF DAN KEMAMPUAN PEMECAHAN MASALAH
}

\author{
Umar Soleh $^{1}$, Ferry Ferdianto ${ }^{2}$, Setiyani ${ }^{3}$ \\ ${ }^{1}$ Universitas Swadaya Gunung Djati \\ Umar.soleh95@gmail.com \\ ${ }^{2}$ Universitas Swadaya Gunung Djati \\ ferrymatematika@gmail.com \\ ${ }^{3}$ Universitas Swadaya Gunung Djati \\ setiyani_0401509081@yahoo.com
}

\begin{abstract}
ABSTRAK
Tujuan penelitian ini adalah untuk mengetahui hubungan model Group Investigation dengan kemampuan berpikir kreatif dan kemampuan pemecahan masalah. Model Group Investigation merupakan model pembelajaran berbasis kelompok dimana siswa diberi peluang untuk berdiskusi, berpikir kritis, dan dapat bertanggung jawab dalam pembelajaran tersebut. Metode penelitian yang dipakai ialah metode eksperimen, dengan teknik pengambilan sampel yang digunakan ialah Purposive Sampling. Instrumen yang digunakan dalam penelitian ini adalah lembar observasi aktivitas siswa, soal tes kemampuan berpikir kreatif dan soal tes kemampuan pemecahan masalah. Uji yang digunakan adalah uji korelasi Pearson Product Moment, uji Factorial ANOVA, serta uji t. Hasil penelitian ini adalah: (1) aktivitas siswa dalam pembelajaran matematika dengan menggunakan model Group Investigation persentase rata-rata keseluruhan mencapai 65,6\% dan termasuk dalam kategori baik; (2) terdapat korelasi model Group Investigation dengan kemampuan berpikir kreatif; (3) terdapat korelasi model Group Investigation dengan kemampuan pemecahan masalah; (4) terdapat korelasi model Group Investigation dengan kemampuan berpikir kreatif dan kemampuan pemecahan masalah; (5) terdapat perbedaan rata-rata kemampuan berpikir kreatif dan kemampuan pemecahan masalah antara siswa kelas eksperimen dan siswa kelas kontrol, dengan nilai rata-rata kelas eksperimen yaitu 76,60 sedangkan nilai rata-rata kelas kontrol yaitu 68,57.
\end{abstract}

Kata Kunci: Group Investigation, Berpikir Kreatif, Pemecahan Masalah.

\begin{abstract}
The aim of this research is to know the relationship of Group Investigation model with creative thinking ability and problem solving ability. Group Investigation Model is a group-based learning model that students are given opportunities to discuss, think critically, and be responsible for the learning. The research method used is experimental method, with sampling technique used is Purposive Sampling. The instrument used in this research are observation sheet of student activity, questions of creative thinking ability and problem solving test problems. The test used is Pearson Product Moment correlation test, ANOVA Factorial test, and t-test. The results of this study are: 1) student activity in learning mathematics by using Group Investigation model overall percentage
\end{abstract}


reaches $65,6 \%$ which in good category; 2) there is correlation of Group Investigation model with creative thinking ability; 3 ) there is correlation of Group Investigation model with problem solving ability; 4) there is a correlation of Group Investigation model with creative thinking ability and problem-solving ability; 5) there is difference of average ability of creative thinking and problem solving ability between experiment class student and control class student, with mean value of experiment class is 76,60 whereas mean value of control class is 68,57 .

Keywords: Group Investigation, Creative Thinking, Problem Solving.

Format Sitasi: Soleh, U., Ferdianto, F. \& Setiyani. (2018). Korelasi Model Group Investigation dengan Kemampuan Berpikir Kreatif dan Kemampuan Pemecahan Masalah. KALAMATIKA Jurnal Pendidikan Matematika, 3(2), 139-154.

Penyerahan Naskah: 7 Januari 2018 || Revisi: 23 Mei 2018 || Diterima: 30 Mei 2018

\section{PENDAHULUAN}

Pada tahun pelajaran 2006/2007, Departemen Pendidikan Nasional melalui Badan Standar Nasional Pendidikan menerapkan Kurikulum 2006 yang lebih dikenal dengan Kurikulum Tingkat Satuan Pendidikan (KTSP). KTSP merupakan penyempurnaan dari kurikulum sebelumnya, yaitu Kurikulum Berbasis Kompetensi. Menurut Departemen Pendidikan Nasional (Effendi, 2012), di dalam KTSP disebutkan bahwa matematika merupakan mata pelajaran yang wajib diberikan kepada seluruh siswa dari mulai jenjang sekolah dasar. Hal itu dikarenakan pembelajaran matematika bertujuan untuk membekali siswa dengan kemampuan berpikir logis, analitis, kreatif, kritis dan sistematis serta mempunyai kemampuan bekerja sama. Demikian pula menurut NCTM (2000), dengan pembelajaran matematika diharapkan siswa memiliki lima standar kemampuan matematis, yaitu: kemampuan pemecahan masalah, kemampuan komunikasi, kemampuan koneksi, kemampuan penalaran, serta kemampuan representasi. Berdasarkan uraian di atas, kemampuan berpikir kreatif dan kemampuan pemecahan masalah menjadi faktor utama pembahasan dalam penelitian ini.

Berdasarkan hasil studi pendahuluan di SMP Negeri 1 Rajagaluh, dapat penulis simpulkan bahwa siswa di sekolah tersebut terbiasa belajar dengan model pembelajaran konvensional (ekspositori). Karena hal itu maka kegiatan aktivitas siswa menjadi kurang aktif. Selanjutnya masih kurangnya kemampuan berpikir kreatif dan kemampuan pemecahan masalah siswa. Hal tersebut telah dibuktikan ketika siswa diberikan soal kemampuan berpikir kreatif dan kemampuan pemecahan masalah, hampir seluruh siswa belum bisa dengan tepat 
menjawab soal yang penulis berikan. Maka berdasarkan hal tersebut maka perlu adanya suatu penyelesaian untuk mengatasinya, salah satu upaya yang dapat ditempuh yaitu dengan menggunakan model Group Investigation.

Model Group Investigation merupakan salah satu model pembelajaran yang memadukan pembelajaran kelompok dengan pembelajaran pemecahan masalah. Senada dengan Ulfa (2015), mengatakan bahwa Group Investigation adalah suatu model pembelajaran kooperatif yang melibatkan siswa dari mulai perencanaan, baik itu dalam menentukan topik maupun cara mempelajarinya melalui investigasi.

Adapun deskripsi mengenai langkah-langkah model Group Investigation menurut Slavin (2009) ada 6 tahap, yaitu: 1) mengidentifikasi topik dan membagi siswa kedalam beberapa kelompok; 2) merencanakan tugas belajar; 3) melaksanakan tugas investigasi; 4) mempersiapkan laporan akhir; 5) menyajikan laporan akhir; dan 6) evaluasi. Berdasarkan uraian tersebut, jika melihat langkah-langkah model Group Investigation dari awal sampai akhir pembelajaran, penulis anggap bisa menjadi solusi penyelesaian permasalah yang telah di jelaskan di atas. Sebagai contoh pada saat siswa melakukan tugas investigasi, siswa dapat mengembangkan kemampuan berpikir kreatif dan kemampuan pemecahan masalah yang saat ini belum dimiliki oleh siswa. Selain itu pada saat langkah menyajikan laporan akhir, siswa seharusnya akan jadi terbiasa untuk mengemukakan pendapatnya dan membaginya kepada siswa lain, hal itulah yang selama ini belum dikembangkan oleh guru.

Berdasarkan uraian permasalah di atas, penulis tertarik untuk melakukan penelitian lebih lanjut pada tingkat SMP dengan memilih judul, "Korelasi Model Group Investigation dengan Kemampuan Berpikir Kreatif dan Kemampuan Pemecahan Masalah". Sedangkan untuk rumusan masalahnya ialah sebagai berikut: 1) bagaimana aktivitas siswa pada pembelajaran menggunakan model Group Investigation?; 2) apakah terdapat korelasi model Group Investigation dengan kemampuan berpikir kreatif siswa?; 3) apakah terdapat korelasi model Group Investigation dengan kemampuan pemecahan masalah siswa?; 4) apakah terdapat korelasi model Group Investigation dengan kemampuan berpikir kreatif dan kemampuan pemecahan masalah siswa?; 5) apakah terdapat perbedaan rata-rata kemampuan berpikir kreatif dan kemampuan pemecahan masalah siswa antara siswa yang mendapat pembelajaran menggunakan model Group Investigation dengan model konvensional? 


\section{METODE PENELITIAN}

Metode penelitian yang digunakan pada penelitian ini adalah metode eksperimen kuasi, metode dengan mengambil sampel tidak secara acak, tetapi dari kelompok yang sudah terbentuk secara alami. Penelitian ini menggunakan desain penelitian berbentuk Control Grup Pre-test Post-test yang melibatkan dua kelompok. Kelompok pertama diberi perlakuan $\left(\mathrm{X}_{1}\right)$, disebut kelompok eksperimen $\left(\mathrm{R}_{\mathrm{E}}\right)$ yang akan diberi perlakuan khusus dengan menggunakan model Group Investigation. Kelompok kedua $\left(\mathrm{X}_{2}\right)$ disebut kelompok kontrol $\left(\mathrm{R}_{\mathrm{K}}\right)$ yang akan diberi perlakuan dengan menggunakan model konvensional (ekspositori). Sehingga pola yang digunakan adalah sesuai dengan pendapat Arikunto (2013) yang dijelaskan sebagai berikut, dengan $\mathrm{O}_{1}$ adalah pretes dan $\mathrm{O}_{2}$ merupakan postes.

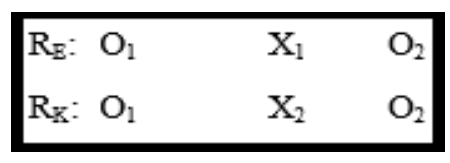

Gambar 1. Desain Penelitian

Kelompok pertama diberi perlakuan (X1), disebut kelompok eksperimen (RE) yang akan diberi perlakuan khusus dengan menggunakan model Group Investigation. Kelompok kedua $\left(\mathrm{X}_{2}\right)$ disebut kelompok kontrol $\left(\mathrm{R}_{\mathrm{K}}\right)$ yang akan diberi perlakuan dengan menggunakan model konvensional (ekspositori).

Populasi dalam penelitian ini adalah seluruh siswa VII SMPN 1 Rajagaluh, tahun ajaran 2015/2016 yang terdiri dari tujuh kelas. Sedangkan yang menjadi sampel pada penelitian ini yaitu dua kelas dari kelas VII SMP Negeri 1 Rajagaluh yang memiliki nilai ratarata relatif sama jika dilihat dari hasil tes ulangan harian. Jadi, dari kedua kelas tersebut yang akan menjadi sampel adalah kelas VII-G sebagai kelas eksperimen dan kelas VII-H sebagai kelas kontrol. Pengambilan sampel tersebut dengan cara Purposive Sample, karena pengambilan sampelnya dengan mempertimbangkan kemampuan kedua kelas yang relatif sama, jumlah kelas kedua kelas tersebut sama, serta pemberian materi yang sama.

Teknik pengumpulan data yang dilakukan pada penelitian ini adalah melaksanakan tes dan observasi. Tes dilakukan untuk mengukur kemampuan berpikir kreatif dan kemampuan pemecahan masalah siswa kelas eksperimen dan kelas kontrol, sedangkan observasi dilakukan untuk melihat aktivitas siswa di kelas eksperimen selama menggunakan model Group 
Investigation. Sehingga instrumen yang digunakan ialah soal tes dan lembar observasi aktivitas siswa.

Soal tes terdiri dari 8 soal tentang: 1) menentukan panjang, lebar, dan luas persegi; 2) menentukan luas segitiga dan segiempat, materi soal juga memuat 2 indikator kemampuan berpikir kreatif dan 2 indikator kemampuan pemecahan masalah. Adapun indikator kemampuan berpikir kreatif menurut Munandar (Prasetyo \& Mubarokah, 2014) yaitu: 1) berpikir lancar; 2) berpikir luwes; 3) berpikir orisinil; 4) keterampilan mengelaborasi. Indikator yang penulis pakai untuk instrumen tes adalah indikator berpikir lancar dan indikator berpikir luwes. Sedangkan untuk indikator kemampuan pemecahan masalah menurut Sumarmo (Jaenab, 2014) yaitu: 1) mengidentifikasi unsur yang diketahui, ditanyakan, dan kecukupan unsur yang diperlukan; 2) merumuskan masalah matematika; 3) menerapkan strategi penyelesaian masalah di dalam dan diluar matematika; 4) menjelaskan hasil pemecahan masalah. Indikator yang dipakai untuk tes dalam penelitian ini hanya indikator 1 dan indikator 2 .

Sedangkan lembar observasi aktivitas siswa terdiri dari 25 pernyataan yang memuat langkah-langkah model Group Investigation dan memuat 6 kegiatan aktivitas siswa. Adapun kegiatan aktivitas siswa menurut Dierich (Hamalik, 2010) yaitu: 1) kegiatan visual; 2) kegiatan lisan; 3) kegiatan mendengarkan; 4) kegiatan menulis; 5) kegiatan menggambar; 6) kegiatan metriks; 7) kegiatan mental; dan 8) kegiatan emosional. Namun 6 kegiatan aktivitas siswa yang akan diamati dalam penelitian ini hanya aktivitas visual, lisan, mendengarkan, menulis, mental, dan emosional. Di dalam pengisian lembar observasi aktivitas siswa, penulis dibantu oleh tiga orang observer selama proses pembelajaran dengan menggunakan model Group Investigation.

Setelah data terkumpul kemudian dianalisis untuk menguji hipotesis dengan bantuan Software SPSS. Teknik analisis data yang digunakan dalam penelitian ini adalah: 1) untuk data hasil observasi aktivitas siswa sebelum dianalisis data tersebut harus diubah terlebih dahulu dari data ordinal ke bentuk data interval dengan menggunakan Method of Successive Interval; 2) uji korelasi Pearson Product Moment untuk menguji hubungan antara aktivitas siswa dengan kemampuan berpikir kreatif ataupun hubungan antara aktivitas siswa dengan kemampuan pemecahan masalah; 3) uji Faktorial ANOVA untuk menguji hubungan antara aktivitas siswa dengan kemampuan berpikir kreatif dan kemampuan pemecahan masalah; dan 
4) uji-t untuk menguji perbedaan rata-rata kemampuan berpikir kreatif dan kemampuan pemecahan masalah siswa antara kelas eksperimen dan kelas kontrol.

\section{HASIL DAN PEMBAHASAN}

Data yang diperoleh dari penelitian ini berupa data kuantitatif dan kualitatif. Data kuantitatif didapatkan melalui tes awal kemampuan berpikir kreatif dan kemampuan pemecahan masalah (pretes) dan tes akhir (postes). Data dari hasil pretes dan postes dalam penelitian ini dibagi kedalam 3 kelompok. Pertama yaitu hasil tes kemampuan berpikir kreatif, kedua hasil tes kemampuan pemecahan masalah, dan ketiga yaitu hasil tes kemampuan berpikir kreatif dan kemampuan pemecahan maslah. Sedangkan untuk data kualitatif didapatkan melalui hasil observasi aktivitas siswa.

\section{Aktivitas Siswa dalam Model Group Investigation}

Aktivitas siswa merupakan hal yang penting di dalam proses belajar mengajar. Menurut Widayanti (2014), tanpa adanya aktivitas siswa di dalam kelas, belajar tidaklah mungkin terjadi. Aktivitas siswa dalam model pembelajaran kooperatif Group Investigation berlangsung sangat baik, pada pertemuan pertama persentase rata-rata aktivitas siswa dalam kategori baik, walaupun siswa masih kebingungan saat mengikuti pembelajaran. Hal ini dikarenakan siswa terbiasa menggunakan model konvensional dari guru, selain itu juga, siswa masih belum bisa bekerja sama dengan baik bersama anggota kelompoknya. Pertemuan kedua dan ketiga mengalami peningkatan dari pertemuan sebelumnya, walaupun persentase masih dalam kategori baik. Berikut merupakan data hasil aktivitas siswa selama tiga pertemuan.

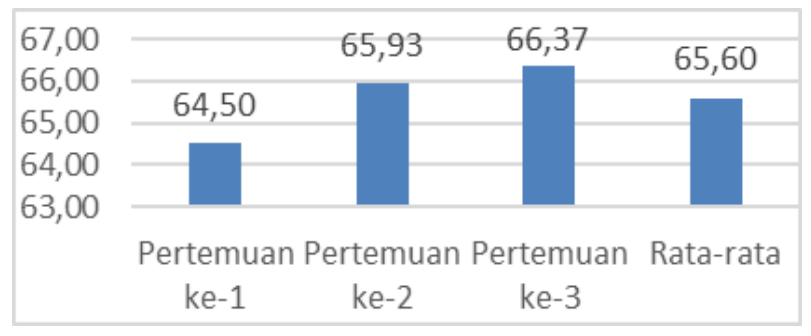

Gambar 2. Persentase Aktivitas Siswa Setiap Pertemuan

Terlihat bahwa dari setiap pertemuan terjadi peningkatan aktivitas siswa masing masing sebesar $1,43 \%$ dan $0,44 \%$ dengan kriteria pada setiap pertemuan adalah baik. Peningkatan tersebut menandakan bahwa siswa memperoleh tingkah laku baru dalam proses pembelajaran. Hal tersebut sesuai dengan pernyataan Sudjana (Timumun, Djirimu \& 
Alibasyah, 2014) bahwa belajar adalah suatu proses yang ditandai dengan adanya perubahan pada diri siswa. Perubahan tersebut ditunjukan dalam berbagai bentuk, seperti berubah pengetahuannya, tingkah lakunya, sikap, kemampuannya serta keterampilannya.

Adapun hasil dari analisis data aktivitas siswa berdasarkan setiap pernyataan, secara keseluruhan pada kegiatan diskusi merupakan aspek yang sangat baik selama pembelajaran dengan menggunakan model Group Investigation. Aktivitas yang menonjol pada kegiatan diskusi kelompok adalah ketika siswa saling memberi dan menerima pendapat anggota kelompoknya untuk menyelesaikan masalah. Hal ini ditunjukan dengan besarnya persentase pada aspek tersebut. Namun pada aktivitas mempresentasikan hasil diskusi, siswa masih terlihat kurang begitu aktif, ini terlihat dari rendahnya persentase aktivitas tersebut. Penyebabnya karena kurang percaya diri siswa ditambah rasa takut salah dan rendahnya minat siswa untuk berbicara di depan kelas.

Berdasarkan uraian tersebut, terlihat bahwa model Group Investigation dapat meningkatkan aktivitas siswa yang ditunjukan dengan terjadinya peningkatan persentase aktivitas siswa setiap pertemuannya. Hal ini sejalan dengan penelitian Artini (2016), yang menyatakan bahwa penggunaan model Group Investigation dapat meningkatkan aktivitas siswa dalam pembelajaran. Begitu juga menurut penilitian yang dilakukan oleh Basuki (2015) yang menyatakan bahwa dengan menggunakan model pembelajaran kooperatif, dapat memberikan peningkatan dalam aktivitas dan hasil belajar siswa. Siswa menjadi lebih terbuka untuk bekerja sama dengan anggota kelompoknya selama diskusi, serta siswa dilatih untuk dapat mencari pola hubungan yang logis untuk dapat menarik sebuah kesimpulan.

\section{Korelasi Model Group Investigation dengan Kemampuan Berpikir Kreatif}

Hasil tes kemampuan berpikir kreatif siswa di kelas eksperimen dan kelas kontrol, didapat nilai rata-rata 8,93 untuk pretes dan 73,70 untuk postes kelas eksperimen. Sedangkan untuk kelas kontrol nilai rata-rata 8,67 untuk pretes dan 61,63 untuk hasil postes. Hasil postes dari kelas eksperimen selanjutnya di uji korelasi dengan data dari aktivitas siswa untuk mengetahui hubungannya dengan menggunakan software SPSS.

Setelah dilakukan uji normalitas dari kedua data tersebut, diketahui bahwa kedua data tersebut berdistribusi normal. Berdasarkan hasil uji korelasi menggunakan uji korelasi Pearson dengan mengambil taraf signifikan $\alpha$ sebesar 5\%, diperoleh nilai koefisien korelasi sebesar 
0,70 dan nilai signifikansi sebesar 0,00. Dikarenakan nilai signifikansi $<0,05$, maka dapat disimpulkan bahwa, terdapat korelasi antara model Group Investigation dengan kemampuan berpikir kreatif.Adapun tingkat keeratan hubungan tersebut berdasarkan Guilford Empirical Rules berada pada kategori kuat, hal itu dikarenakan besarnya koefiseien korelasinya terletak diantara 0,70 dan 0,90 .

Kuatnya hubungan aktivitas siswa yang menggunakan model Group Investigation pada kemampuan berpikir kreatif dikarenakan adanya pembiasaan pola berpikir yang kreatif pada siswa selama proses belajar di dalam kelas. Di awal pembelajaran menggunakan model Group Investigation, siswa dibiasakan untuk topik bahasan yang akan mereka pelajari bersama kelompoknya, selanjutnya siswa dibiasakan untuk bisa merencanakan terlebih dahulu prosedur investigasi bersama kelompoknya.

Selain itu, faktor soal latihan juga menurut penulis sangat berpengaruh, baik itu soal yang dikerjakan kelompok maupun soal latihan individu. Soal latihan yang diberikan biasanya menuntut siswa supaya dapat menyelesaikannya dengan dua cara yang berbeda, hal itu sesuai dengan indikator berpikir kreatif berpikir lancar walaupun siswa kelas kontrol juga mendapatkan soal latihan dengan jenis yang sama, tetapi siswa di kelas kontrol lebih cenderung menjawab soal dengan mencontoh cara penyelesaian yang telah penulis berikan sebelumnya.

Sedangkan pada kelas eksperimen, siswa bisa memberikan strategi yang beragam jika menyelesaikan soal kemampuan berpikir kreatif. Hal itu dikarenakan siswa kelas eksperimen yang menggunakan model Group Investigation mendapatkan lebih banyak cara ataupun strategi penyelesaian masalah pada saat mereka berdiskusi. Pada saat kegiatan diskusi kelompok ini, siswa dituntut untuk dapat saling memberikan pendapatnya kepada anggota kelompoknya. Sesuai dengan penelitian Nur \& Abdullah (2014) dengan kerja sama kelompok siswa dalam model pembelajaran kooperatif siswa dapat membantu temannya satu sama lain serta siswa lebih dapat mementingkan kepentingan kelompoknya dari pada kepentingan pribadi.

Jika dibandingkan antara siswa kelas eksperimen dan siswa kelas kontrol yang menggunakan model pembelajaran konvensional, untuk nilai rata-rata hasil postes kemampuan berpikir kreatif siswa terdapat perbedaan yang signifikan. Besarnya nilai rata-rata postes kelas eksperimen yaitu 73,70 sedangkan untuk kelas eksperimen yaitu hanya 61,63, itu menunjukan 
bahwa siswa kelas eksperimen dapat mencapai nilai ketuntasan minimal untuk kemampuan berpikir kreatif. Hal itu sesuai dengan hasil penelitian yang dilakukan oleh Rahmawati (2014), yang menyatakan bahwa kemampuan berpikir kreatif siswa yang mendapatkan pembelajaran dengan model pembelajaran kooperatif Group Investigation dapat mencapai hasil yang signifikan untuk ketuntasan individual.

Berdasarkan uraian tersebut, penulis menyimpulkan bahwa terdapat hubungan antara model Group Investigation dengan kemampuan berpikir kreatif siswa. Arah hubungan model Group Investigation dengan kemampuan berpikir kreatif juga menunjukan arah hubungan yang positif, artinya semakin tinggi nilai aktivitas siswa selama proses pembelajaran, maka semakin tinggi juga nilai kemampuan berpikir kreatif siswa.

\section{Korelasi Model Group Investigation dengan Kemampuan Pemecahan Masalah}

Hasil tes kemampuan pemecahan masalah siswa didapat nilai rata-rata 1,43 untuk pretes dan 81,20 untuk postes kelas eksperimen. Sedangkan kelas kontrol nilai rata-ratanya 2,10 untuk pretes dan 77,73 untuk hasil postes. Hasil postes dari kelas eksperimen selanjutnya di uji korelasi dengan data dari aktivitas siswa untuk mengetahui hubungannya dengan menggunakan software SPSS.

Setelah dilakukan uji normalitas dari kedua data tersebut, diketahui bahwa kedua data tersebut berdistribusi normal. Berdasarkan hasil uji korelasi menggunakan uji korelasi Pearson dengan mengambil taraf signifikan $\alpha$ sebesar 5\%, diperoleh nilai koefisien korelasi sebesar 0,74 dan nilai signifikansi sebesar 0,00. Dikarenakan nilai signifikansi < 0,05, maka dapat disimpulkan bahwa terdapat korelasi antara model Group Investigation dengan kemampuan pemecahan masalah. Adapun tingkat keeratan hubungan tersebut berdasarkan Guilford Empirical Rules berada pada kategori kuat, hal itu dikarenakan besarnya koefiseien korelasinya terletak diantara 0,70 dan 0,90.

Besarnya pengaruh model Group Investigation terhadap kemampuan pemecahan masalah juga lebih tinggi dari pada besarnya pengaruh terhadap kemampuan berpikir kreatif. Hal itu dikarenakan nilai postes kemampuan pemecahan masalah kelas eksperimen nilai rataratanya teah mencapai 81,2 . Sedangkan untuk nilai rata-rata kemampuan pemecahan masalah kelas kontrol yaitu sebesar 77,73. Kedua nilai lebih baik jika dibandingkan dengan perolehan nilai rata-rata dari kemampuan berpikir kreatif. Namun tetap jika dilihat kembali hasil 
tersebut, nilai rata-rata kemampuan pemecahan masalah kelas eksperimen hasilnya lebih baik daripada nilai rata-rata kelas kontrol yang menggunakan model pembelajaran konvensional. Hal itu sesuai dengan hasil penelitian Ulfa (2015), yang menyatakan bahwa kemampuan pemecahan masalah siswa yang menggunakan model Group Investigation lebih besar dari pada siswa yang menggunakan model pembelajaran konvensional. Begitu juga berdasarkan penelitian Hertiavi, dkk. (2016) yang menyatakan bahwa kemampuan pemecahan masalah siswa setelah menerapkan model pembelajaran kooperatif mengalami peningkatan dan memenuhi indikator keberhasilan.

Arah hubungan model Group Investigation dengan kemampuan pemecahan masalah juga menunjukan arah hubungan yang positif, artinya semakin tinggi nilai aktivitas siswa selama proses pembelajaran, maka semakin tinggi juga nilai kemampuan pemecahan masalah siswa. Hal itu berarti sikap siswa selama proses pembelajaran menggunakan model Group Investigation secara umum memiliki sikap yang positif. Sikap positif tersebut menurut Asri, Ikhsan \& Ramli (2014) lebih membantu siswa memahami materi yang sedang mereka pelajari.

Kegiatan aktivitas siswa yang berpengaruh besar terhadap adanya hubungan model Group Investigation dengan kemampuan pemecahan masalah, yaitu pada kegiatan merencanakan langkah-langkah yang akan siswa lakukan dalam menyelesaikan tugas kelompoknya. Hal itu juga membiasakan siswa untuk dapat menyelesaikan suatu masalah dengan menggunakan langkah-langkah penyelesaian masalah.

Adapun hal lain yang mempengaruhinya ialah kegiatan aktivitas siswa pada saat siswa mengoreksi kembali hasil kerja kelompoknya, dengan pembiasan aktivitas itu siswa menjadi lebih teliti lagi melihat apakah hasil kerjanya telah diselesaikan dengan tepat apa belum.Hal tersebut menunjukan pentingnya pemeriksaan kembali setelah menyelesaikan suatu permasalah. Menurut Polya (Mulyadi, 2014) dengan mengecek kembali, siswa dapat mencari kemungkinan penyelesaian dan cara yang berbeda untuk menyelesaikan masalah yang sama. Berdasarkan uraian tersebut, penulis menyimpulkan bahwa terdapat hubungan antara model Group Investigation dengan kemampuan pemecahan masalah siswa.

\section{Korelasi Model Group Investigation dengan Kemampuan Berpikir Kreatif dan Pemecahan Masalah}

Uji yang digunakan untuk mengetahui hubungan antara model Group Investigation dengan kemampuan berpikir kreatif dan kemampuan pemecahan masalah adalah uji faktorial 
ANOVA. Data yang digunakan ialah data aktivitas siswa serta nilai rata-rata postes kemampuan berpikir kreatif dan nilai rata-rata postes kemampuan pemecahan masalah kelas eksperimen. Berikut adalah hasil dari uji faktorial ANOVA dengan menggunakan SPSS, Lestari \& Yudhanegara (2015).

Tabel 1. Hasil Uji Faktorial ANOVA

\begin{tabular}{cccccc}
\hline & Type III & & Mean & & \\
Source & Sum of & df & S & Square & F \\
& Squares & & & \\
\hline Corrected Model & $6694.260^{\mathrm{a}}$ & 25 & 267.770 & 2.914 & .002 \\
Intercept & 155903.565 & 1 & 155903.565 & 1696.805 & .000 \\
K.Berpikir_Kreatif*K.Pemecahan_Masalah & 6694.260 & 25 & 267.770 & 2.914 & .002 \\
Error & 3123.943 & 34 & 91.881 & & \\
Total & 258397.120 & 60 & & & \\
Corrected Total & 9818.203 & 59 & & & \\
\hline
\end{tabular}

a. R Squared $=.682($ Adjusted R Squared $=.448)$

Dependent Variable: Aktivitas_Siswa

Hasil dari uji Faktorial ANOVA pada tabel 1, dengan mengambil taraf signifikansi $\alpha$ sebesar 5\%, diperoleh nilai signifikansi sebesar 0,002. Dikarenakan nilai $\rho$-value dari data tersebut lebih kecil dari nilai $\alpha(0,05)$, maka disimpulkan bahwa terdapat korelasi model Group Investigation dengan kemampuan berpikir kreatif dan kemampuan pemecahan masalah.

Berdasarkan kegiatan yang terdapat pada aktivitas siswa dengan menggunakan model kooperatif Group Investigation, kegiatan yang penulis anggap dapat mampu memberikan pengaruh yang cukup signifikan terhadap kemampuan berpikir kreatif dan kemampuan pemecahan masalah adalah kegiatan visual, kegiatan mendengarkan, kegiatan menulis, serta kegiatan mental. Terlihat dari besarnya persentase pada kegiatan tersebut.

Berdasarkan hal tersebut, penulis beranggapan bahwa model Group Investigation dapat membantu sekaligus membimbing siswa yang masih belum memahami materi yang sedang dipelajari menjadi lebih paham sehingga dapat meningkatkan hasil belajarnya. Siswa pandai akan membimbing temannya yang lemah, karena keberhasilan pembelajaran kelompok ditentukan oleh keberhasilan masing-masing anggota kelompoknya (Yensy, 2012).

\section{Perbedaan Rata-rata Kemampuan Berpikir Kreatif dan Kemampuan Pemecahan Masalah antara Siswa Kelas Eksperimen dan Siswa Kelas Kontrol}

Berdasarkan hasil tes kemampuan berpikir kreatif dan kemampuan pemecahan masalah (nilai total), dapat diketahui bahwa nilai rata-rata kelas eksperimen untuk pretes ialah 5,17 dan untuk postes ialah 76,60. Sedangkan untuk nilai rata-rata kelas kontrol ialah 5,30 untuk nilai 
pretes dan 68,57 untuk nilai postes. Nilai postes dari kedua kelas tersebut di uji menggunakan uji $t$.

Berdasarkan hasil perhitungan uji $t$ pada data tersebut didapat nilai signifikansi sebesar 0,005 , nilai tersebut lebih kecil dari $\alpha=0,05$. Artinya terdapat perbedaan rata-rata kemampuan berpikir kreatif dan kemampuan pemecahan masalah antara siswa kelas eksperimen yang menggunakan model Group Investigation dengan siswa kelas kontrol yang, menggunakan model pembelajaran konvensional.

Jika dilihat dari nilai rata-rata postes jelas terlihat bahwa nilai rata-rata kelas eksperimen hasilnya lebih baik dan telah mencapai KKM. Hal itu dikarenakan pada kelas kontrol yang menggunakan model konvensional. Pembelajaran konvensional kurang membangkitkan motivasi siswa untuk belajar sehingga kemampuan berpikir kreatif dan kemampuan pemecahan masalah yang lebih rendah dibandingkan dengan kelas eksperimen. Sedangkan pada kelas yang mendapat pembelajaran dengan model Group Investigation, siswa selalu dibiasakan untuk aktif selama proses pembelajaran, baik ketika ditanya, bertanya, ataupun ketika diskusi kelompok berlangsung. Hal tersebut sesuai dengan pendapat Husna \& Fatimah (2013) bahwa hasil belajar siswa dengan menggunakan model pembelajaran kooperatif lebih baik dibandingkan dengan menggunakan model pembelajaran konvensional.

Faktor keberhasilan sebuah proses pembelajaran selain karena pemilihan model pembelajaran yang tepat, kemandirian belajar siswa juga akan menentukan keberhasilan pembelajaran, hal tersebut berdasarkan yang dinyatakan oleh Fitriana (2011). Di dalam model Group Investigation kemandirian siswa jelas ditanamkan dalam diri masing-masing siswa.

\section{KESIMPULAN}

Berdasarkan analisis data dan pembahasan hasil penelitian maka diperoleh simpulan bahwa aktivitas siswa dalam pembelajaran matematika dengan menggunakan model Group Investigation secara keseluruhan berada pada kategori yang baik, hal itu ditandai dengan perolehan nilai rata-rata aktivitas siswa dari tiga pertemuan yaitu sebesar $65,60 \%$. Aktivitas yang menonjol pada kegiatan diskusi kelompok, namun pada aktivitas mempresentasikan hasil diskusi siswa masih kurang begitu aktif. Selain itu, terdapat korelasi antara model Group Ivestigation dengan kemampuan berpikir kreatif siswa, yang ditandai dengan besarnya nilai koefisien korelasi antara aktivitas siswa dengan kemampuan berpikir kreatif sebesar 0,70. Nilai tersebut menunjukan bahwa adanya keeratan hubungan antara model Group 
Investigation dengan kemampuan berpikir kreatif siswa, serta memiliki arah yang positif. Terdapat korelasi antara model Group Ivestigation dengan kemampuan pemecahan masalah siswa, yang ditandai dengan besarnya nilai koefisien korelasi antara aktivitas siswa dengan kemampuan pemecahan masalah sebesar 0,74. Nilai tersebut menunjukan bahwa adanya keeratan hubungan antara model Group Investigation dengan kemampuan pemecahan masalah siswa, serta memliki arah yang positif .

\section{REKOMENDASI}

Jika akan melakukan penelitian selanjutnya, diharapkan dapat mengkaji lebih dalam lagi mengenai indikator kemampuan berpikir kreatif, diharapkan semua indikator kemampuan tersebut dapat dipakai agar hasilnya lebih maksimal. Selain itu, pada kemampuan pemecahan masalah siswa, sebaiknya pada langkah-langkah penyelesaian masalah siswa lebih ditekankan lagi untuk dapat menyelesaikan suatu soal dengan langkah-langkah penyelesaian masalah berdasarkan Polya. Siswa pada penelitian ini masih banyak yang tidak mencantumkan fase rencana penyelesaian dan fase memeriksa kembali. Hal itu berakibat pada perolehan skor jawaban siswa yang tidak maksimal.

Kekurangan penelitian ini, pada saat pengaturan tempat duduk untuk siswa berdiskusi mengakibatkan pemakaian alokasi waktu yang lumayan banyak. Dianjurkan untuk pembelajaran kelompok, pada saat sebelum pelajaran dimulai seharusnya siswa sudah siap duduk bersama anggota kelompoknya.

\section{REFERENSI}

Arikunto, S. (2013). Dasar-Dasar Evaluasi Pendidikan Edisi 2. Jakarta: Bumi Aksara.

Artini, A. (2016). Penerapan Model Pembelajaran Kooperatif Tipe Group Investigation untuk Meningkatkan Aktivitas dan Hasil Belajar IPA pada Siswa Kelas VI SD Inpres 1 Tondo. Mitra Sains, 4(1).

Asri, K., Ikhsan, M., \& Ramli, M. (2014). Meningkatkan Kemampuan Pemecahan Masalah dan Komunikasi Matematis melalui Penerapan Pembelajaran Kooperatif Tipe Jigsaw pada Siswa Sekolah Menengah Atas. Jurnal Didaktik Matematika, 1(2). 
Basuki, N. (2015). Peningkatan Aktivitas dan Hasil Belajar Siswa Menggunakan Model Pembelejaran Kooperatif Tipe Jigsaw pada Mata Pelajaran Matematika Siswa Kelas VII SMPN2 Bumiratu Nuban Tahun Pelajaran 2014/2015. AKSIOMA: Jurnal Program Studi Pendidikan Matematika, 4(1).

Effendi, L. A. (2012). Pembelajaran Matematika dengan Metode Penemuan Terbimbing untuk Meningkatkan Kemampuan Representasi dan Pemecahan Masalah Matematis Siswa SMP. Jurnal Penelitian Pendidikan, 13(2).

Fahradina, N., \& Ansari, B. I. (2014). Peningkatan Kemampuan Komunikasi Matematis dan Kemandirian Belajar Siswa SMP dengan Menggunakan Model Investigasi Kelompok. Jurnal Didaktik Matematika, 1(2).

Fitriana, L. (2011). Pengaruh Model Pembelajaran Cooperative Tipe Group Investigation (GI) dan STAD terhadap Prestasi Belajar Matematika Ditinjau dari Kemandirian Belajar Siswa. Prosiding. ISBN: 978-979-16353-6-3.

Hamalik, O. (2010). Kurikulum dan Pembelajaran. Jakarta: Bumi Aksara.

Hertiavi, M. A., Langlang, H., \& Khanafiyah, S. (2016). Penerapan model pembelajaran kooperatif tipe jigsaw untuk peningkatan kemampuan pemecahan masalah siswa SMP. Jurnal Pendidikan Fisika Indonesia, 6(1).

Husna, M., \& Fatimah, S. (2013). Peningkatan kemampuan pemecahan masalah dan Komunikasi matematis siswa Sekolah Menengah Pertama melalui model pembelajaran kooperatif tipe Think-pair-share (TPS). Jurnal Peluang, 1(2), 81-92.

Jaenab, S. (2014). Pembelajaran Matematika untuk Meningkatkan Kemampuan Pemecahan Masalah Matematis siswa Sekolah Menengah Kejuruan. Prosiding Seminar Nasional Pendidikan Matematika Program Pasca Sarjana STKIP Siliwangi Bandung. ISSN: 2355-0473.

Lestari, K. A., Yudhanegara, M. R. (2015). Penelitian Pendidikan Matematika. Bandung: Refika Aditama. 
Mulyadi, Y. (2014). Pemecahan Masalah Matematika. Prosiding Seminar Nasional Pendidikan Matematika Program Pasca Sarjana STKIP Siliwangi Bandung. ISSN: 2355-0473.

National Council of Teachers of Mathematics (Ed.). (2000). Principles and standards for school mathematics (Vol. 1). National Council of Teachers of.

Nur, I.M., \& Abdullah, I.H. (2014). Pengaruh Model Pembelajaran Kooperatif Tipe Jigsaw untuk Meningkatkan Kemampuan Berpikir Kreatif dan Soft Skill Matematis Siswa SMA. Jurnal Matematika dan Pendidikan Matematika. ISSN: 2089-855X.

Prasetyo, A. D., \& Mubarokah, L. (2014). Berpikir Kreatif Siswa Dalam Penerapan Model Pembelajaran Berdasar Masalah Matematika. Jurnal Pendidikan Matematika STKIP PGRI Sidoarjo, 2(1), 1-10.

Rahmawati, D. (2014). Implementasi Group Investigation dengan Scientific Approach Berbasis Portofolio Terhadap Kemampuan Berpikir Kritis Matematis. Unnes Journal of Mathematics Education, 3(3).

Slavin, R.E. (2009). Psikologi Pendidikan: Teori dan Praktek Jilid 2. Jakarta: PT Indeks.

Timumun, H. M., Djirimu, M. L., \& Alibasyah, L. M. (2014). Meningkatkan Hasil Belajar Siswa Melalui Penerapan Pembelajaran Kooperatif Tipe Stad Pada Mata Pelajaran IPA di Kelas V SDN 10 Biau. Jurnal Kreatif Tadulako Online, 5(3).

Ulfa, S. (2015). Penerapan Model Pembelajaran Group Investigation Melalui Strategi Problem Based Learning terhadap Kemampuan Memecahkan Masalah Fisika Siswa MA NU Mu'allimat Kudus Kelas X. UPEJ Unnes Physics Education Journal, 4(1).

Widayanti, L. (2014). Peningkatan Aktivitas Belajar dan Hasil Belajar Siswa dengan Metode Problem Based Learning pada Siswa Kelas VIIA MTs Negeri Donomulyo Kulon Progo Tahun Pelajaran 2012/2013. Jurnal Fisika Indonesia, 17(49). 
Yensy, N. A. (2012). Penerapan Model Pembelajaran Kooperatif Tipe Examples Non Examples dengan Menggunakan Alat Peraga untuk Meningkatkan Hasil Belajar Siswa di Kelas VIII SMP N 1 Argamakmur. Exacta, 10(1), 24-35. 